\title{
Gender Gap in Academic Achievement in Brunei Tertiary Education: Qualitative Perspective
}

\author{
Halimaturradiah Metussin
}

Sultan Hassanal Bolkiah Institute of Education, Universiti Brunei Darussalam, Bandar Seri Begawan, Brunei Darussalam.

\begin{abstract}
This study explores the potential factors causing a gender gap in academic achievement in the higher learning institutions of Brunei using in-depth interviews. Given that the gender gap is a worldwide phenomenon and problem in many educational settings, this study investigates the reasons for its persistence and how it can be resolved in the Brunei context. The findings of the study indicate that: 1) there are gender similarities in practices of good academic performance at school; 2) teaching methods and school facilities and environment may affect students' academic performance; 3) problems or challenges faced in academic performance or achievement at school; and 4) early entry to workplace. A mixed-methods research is recommended to gain additional insights into the problem and its solutions.
\end{abstract}

Keywords: Gender gap, academic achievement, gender differences, tertiary education, qualitative methods.

\section{Introduction}

In Brunei, ample statistical evidences indicate the existence of gender disparity in academic achievement between female and male students (Department of Planning, Development and Research, 2010; Department of Statistics, 2011). The difference in numbers of males and females enrolling in Brunei tertiary educational institutions cannot attributed to differences in the critical vital life incidence statistics (such as birth rates, infant mortality, diseases, accidents and death). Further, school enrolment rates show that a nearly equal number of boys and girls enter school each year, and are retained in the education system until they complete their General Certificate of Education (GCE) Ordinary (O) Levels (Year 11) (Department of Planning, Development and Research, 2010). Moreover, the difference in the school dropout rate by gender is not statistically significant throughout the education system. Only a few children (mostly boys) repeat one year during their schooling due to a variety of reasons, including illness, disability or poor performance.

Throughout all the levels, particularly from GCE O Level (Year 11) to Advanced (A) Level (Year 13), the Special Education Unit and Guidance and Counselling Unit from the Ministry of Education provide personal counselling and educational interventions to students with special needs and poor academic achievements. As a result, equal girls and boys enrol in the few available sixth form colleges that serve as a pre-university foundation stage. Thus, overall, students are accorded a fair opportunity to access college and university education in Brunei.

In addition, the college and university statistics also indicate a significant prevalence of males in vocational and technical institutions, whereby there are more males in technical courses or programs such as engineering. In contrast, females represent the majority of enrolments in other courses. The other factor that may be held accountable for the gender gap is the gender differences in career interests. Documented employment statistics indicate that the majority of male school leavers opt to join the security services (police, army and prisons department) after completing school. Hence, more males than females join the uniformed services as recruits and cadet officers.

Therefore, in terms of academic performance or achievement, the gender gap appears to arise during the GCE AS and A Levels (Years 12 to 13). It is at this stage that it appears that females begin to far outperform their male counterparts in key subjects, such as mathematics and English, which are frequently included among the admission criteria of colleges and universities in Brunei. This has resulted in fewer males than females being admitted to colleges and universities.

\section{Factors Impacting Academic Performance / Achievement in Brunei}

Taking into consideration the fact that both genders are raised in the same culture, attend similar schools, and are taught by teachers with comparable qualifications and experience, the causes of the difference in academic performance at the 
AS and A Levels is puzzling and remains a mystery to many educational stakeholders, such as teachers, parents and employers. In general, the low performance in important key subjects such as mathematics and English, could be due to a number of reasons such as the poor quality of teaching, inadequate or inappropriate learning resources, and low interest or motivation in the subject. The National Education System for the 21 ${ }^{\text {st }}$ Century (SPN21) (Mundia, 2010a) and teacher education innovation in 2009 (Mundia, 2012a) are among the few examples of educational interventions made by the Ministry of Education to improve the quality of education.

It is a known fact that students with personal and academic problems have higher chances of low academic performance and achievement compared to those students with no problems. This is because their learning ability is affected and it limits their academic potentials. Negative factors, such as disability, behavioural disorders, depression, anxiety and stress are psychological and require counselling interventions to address them at school and at home (Mundia, 2006; Mundia, 2010b; Tait \& Mundia, 2012b). In addition, differences in career preferences might also lead students to develop varying levels of interest and motivation for studying subjects (Mundia, 1998).

\section{Objectives of the Study}

In general, it is well known that a student's academic achievement and grades are affected by numerous factors-too numerous to mention all here-that operate at different levels. These factors could include students' personal attributes, the home environment, the school context, teaching effectiveness, school quality, the nature of the curriculum, assessment procedures and language facility difficulties (to name a few). Each of these factors is broad and encompasses a wide range of issues. Thus far, no research is known to have been conducted in Brunei to determine the extent to which each of these factors influence the gender difference in AS and A Level academic performance. The three main objectives of the present study were to:

To explain gender disparity in academic achievement Brunei tertiary education.

To understand the onset of gender gap in academic achievement in Brunei tertiary education.

To seek any initiatives to reduce gender differences in Brunei tertiary education.

\section{Method}

Design

The in-depth interviews method was used to investigate the problem. Under this procedure, the researcher had purposeful interactions to learn what another person knows, to discover and record what the person has experienced, what he or she thinks and feels about it, and what significance or meaning it might have (Arthur, Waring, Coe and Hedges, 2012, p. 170). This method required a good preparation before conducting the research and a great attention to participants during the interview to enable insightful analysis and produce firm findings (Dato Haji Metussin, 2016). Additionally, this method allows the researcher to receive in-depth information from the participants while controlling the line of questioning (Creswell, 2009). Moreover, the interview method can answer the 'what', 'how' and 'why' of the research questions by selecting participants to acquire in-depth detail. Additionally, in this study, there was no chance of the participants' behavioural patterns being influenced by the researcher because the researcher was asking about their feelings or actions regarding their academic achievement in the past. Therefore, the in-depth interview method was suitable for this study.

\section{Sample}

The non-probability sample consisted of a few information-rich cases (selected either purposefully or via the snowball procedure) who served as key informants in the semi-structured interview component of the study. Both genders were recruited in this sample. Two inclusion criteria - both based on sixth-form college/school academic records -were used to identify suitable participants. First, this study selected and interviewed previous male and female students who failed mathematics and English at the A Level and did not meet university admission requirements. These former sixth-form college students were currently out of school, working or in institutions of learning other than universities (such as vocational and technical establishments). During the interviews, these participants were asked to explain why they thought they did not perform well in mathematics and English. Second, this study selected and interviewed previous male and female students who passed mathematics and English at the A Level and met the university admission requirements. These former 
sixth-form college students were currently in their first year of university or in institutes of higher learning in Brunei. During the interviews, these participants were asked to explain why they thought they performed well in mathematics and English.

The interview schedule (which was pretested on similar types of people prior to use) also collected demographic information, such as the participants' age, present occupation or training program, parents' education and occupation, number of siblings, and any other relevant data useful in describing the qualitative sample. The size of the sample in the pilot study was 20 , and in the main study was 32 . The sample's descriptive statistics for the main study are presented in Tables 1 and 2 below.

Table 1

General Demographic Information of the Main Study from the Qualitative Interviews ( $N=32$ )

\begin{tabular}{|c|c|c|c|c|c|}
\hline Variable & Group & \multicolumn{2}{|l|}{ Frequency } & \multicolumn{2}{|c|}{ Percentage (\%) } \\
\hline \multirow[t]{3}{*}{ Gender } & $\begin{array}{l}\text { Females } \\
\text { Males }\end{array}$ & \multicolumn{2}{|l|}{$\begin{array}{l}16 \\
16 \\
\end{array}$} & \multicolumn{2}{|l|}{$\begin{array}{l}50 \\
50 \\
\end{array}$} \\
\hline & & \multicolumn{2}{|c|}{ MALE INTERVIEWEES } & \multicolumn{2}{|c|}{ FEMALE INTERVIEWEES } \\
\hline & & Frequency & Percentage (\%) & Frequency & Percentage $(\%)$ \\
\hline & Islam & 16 & 50 & 15 & 46.88 \\
\hline Religion & Christian & $\begin{array}{l}0 \\
0\end{array}$ & & $\begin{array}{l}0 \\
1\end{array}$ & $\begin{array}{l}0 \\
3.13\end{array}$ \\
\hline Ethnicity & $\begin{array}{l}\text { Malay } \\
\text { Chinese } \\
\text { Dusun } \\
\text { Tutong } \\
\text { Belait } \\
\text { Murut } \\
\text { Kedayan } \\
\text { Bisaya }\end{array}$ & $\begin{array}{l}14 \\
0 \\
1 \\
1 \\
0 \\
0 \\
0 \\
0\end{array}$ & $\begin{array}{l}43.75 \\
0 \\
3.13 \\
3.13 \\
0 \\
0 \\
0 \\
0\end{array}$ & $\begin{array}{l}15 \\
1 \\
0 \\
0 \\
0 \\
0 \\
0 \\
0\end{array}$ & $\begin{array}{l}46.88 \\
3.13 \\
0 \\
0 \\
0 \\
0 \\
0 \\
0\end{array}$ \\
\hline Parental status & $\begin{array}{l}\text { Married } \\
\text { Separated or } \\
\text { divorced } \\
\text { Widowed } \\
\text { Deceased }\end{array}$ & $\begin{array}{l}15 \\
1 \\
0 \\
0\end{array}$ & $\begin{array}{l}46.88 \\
3.13 \\
0 \\
0\end{array}$ & $\begin{array}{l}14 \\
1 \\
0 \\
1\end{array}$ & $\begin{array}{l}43.75 \\
3.13 \\
0 \\
3.13\end{array}$ \\
\hline Father's highest level of education & $\begin{array}{l}\text { Primary } \\
\text { Secondary } \\
\text { College } \\
\text { University } \\
\text { Missing data }\end{array}$ & $\begin{array}{l}0 \\
7 \\
4 \\
5 \\
0\end{array}$ & $\begin{array}{l}0 \\
21.88 \\
12.50 \\
15.63 \\
0\end{array}$ & $\begin{array}{l}1 \\
7 \\
3 \\
4 \\
1\end{array}$ & $\begin{array}{l}3.13 \\
21.88 \\
9.38 \\
12.50 \\
3.13\end{array}$ \\
\hline Mother's highest level of education & $\begin{array}{l}\text { Primary } \\
\text { Secondary } \\
\text { College } \\
\text { University }\end{array}$ & $\begin{array}{l}1 \\
9 \\
2 \\
4\end{array}$ & $\begin{array}{l}3.13 \\
28.13 \\
6.25 \\
12.50\end{array}$ & $\begin{array}{l}2 \\
6 \\
2 \\
6\end{array}$ & $\begin{array}{l}6.25 \\
18.75 \\
6.25 \\
18.75\end{array}$ \\
\hline
\end{tabular}

Table 2

Occupation of the Interviewees' Father and Mother According to Frequency and Percentage ( $N=32)$

\begin{tabular}{lllllll}
\hline \multirow{2}{*}{ Variable } & \multicolumn{2}{l}{ MALE INTERVIEWEES } & \multicolumn{3}{l}{ FEMALE INTERVIEWEES } \\
& Group & Frequency & $\begin{array}{l}\text { Percentage } \\
(\%)\end{array}$ & Group & Frequency & $\begin{array}{l}\text { Percentage } \\
(\%)\end{array}$ \\
\hline & 2 & 2 & 6.25 & 00 & 2 & 6.25 \\
& 5 & 1 & 3.13 & 8 & 2 & 6.25 \\
Father's occupation & 6 & 1 & 3.13 & 11 & 1 & 3.13 \\
& 8 & 2 & 6.25 & 15 & 5 & 15.63 \\
& 16 & 4 & 12.50 & 16 & 2 & 6.25 \\
& 17 & 1 & 3.13 & 17 & 1 & 3.13 \\
& 22 & 5 & 15.63 & 22 & 3 & 9.38 \\
\hline
\end{tabular}




\begin{tabular}{lllllll}
\hline TOTAL & - & 16 & 50 & - & 16 & 50 \\
& 15 & 5 & 15.63 & 10 & 1 & 3.13 \\
\multirow{3}{*}{ Mother's occupation } & 17 & 4 & 12.50 & 15 & 2 & 6.25 \\
& 21 & 6 & 18.75 & 17 & 7 & 21.88 \\
& 22 & 1 & 3.13 & 20 & 1 & 3.13 \\
& - & - & - & 21 & 4 & 12.50 \\
\hline TOTAL & - & - & - & 22 & 1 & 3.13 \\
\hline
\end{tabular}

Note: Please refer to Appendix I for the major occupation groups in the 'Group' column, under the occupation of the father and mother row.

\section{Procedures}

This study was originally done as part of the $\mathrm{PhD}$ doctoral dissertation research using sponsorship funds from the Universiti Brunei Darussalam. Permission to collect the data from the Sixth Form Centres (schools) was obtained from the Ethical Committee of the University. In addition, permission to conduct the study in schools was also granted by the Ministry of Education in the Government of Brunei Darussalam. Ethical requirements for involvement in the study were explained to all the participants. No deception was used. Only students who voluntarily agreed to participate in the study were recruited as participants and they were required to sign an informed consent form. Participants were also asked before the interviews were recorded. Names of the six participating schools and participants were concealed.

\section{Data Analysis}

The present qualitative data obtained from semi-structured interviews were embedded in the interview transcripts. The data analysis began after transcribing the interview audio recorded, not during the field.

The qualitative data in the present study were analysed in two main ways: content analysis and constant comparison (Lincoln \& Guba, 1985; Patton, 1990). Under content analysis, the researcher carefully read through the literal text or information and looked for words, phrases, approaches of thinking and events that recurred frequently and seemed important. This was done manually. The major purpose of content analysis in this study was two-fold. First, the researcher coded the data and reduced it to a few easily recognisable identical or similarly coded patterns. Second, the researcher used the codes to identify patterns, classify the patterns into categories, develop category descriptors, and organise related categories into themes. The process of content analysis often results in three main types of categories. 'Emic' categories contain information directly provided by the participants in their own language or words during the interview. 'Etic' categories reflect the researcher's interpretation of emic data. 'Residual' categories consist of information that does not fit into any other existing categories after analysing the data repeatedly and exhaustively.

Via constant comparison, the researcher iteratively: 1) synthesised and compared each unit or category of meaning to other selected units of meaning; 2) established new categories and new themes if similar units were not found; 3 ) looked for relationships across categories and themes. The themes should be mutually exclusive and distinct from each other. In the present study, quotations, excerpts, frequencies and percentages were used together with categories and themes whenever and wherever necessary. The codebook is produced in the end of the data analysis.

\section{Results}

Gender similarities in practices of good academic performance at school.

The interviews indicated gender similarities in practices of good academic performance at school. This included making notes during lessons or obtaining notes from seniors. Some respondents used their time to study alone at least one hour per day with full concentration, self-motivation and self-discipline, while others preferred to have study groups with friends. The respondents undertook reading and homework and answered past years' examination questions regularly as part of their revision:

'I write my own notes... and revise previous subjects" (Working Male 1).

口'I do my homework, always' (Male Student 1). 
['I study hard for my exams' (Working Female 3).

प'I study alone better, while listening to music' (Male Student 4).

口 'I study better with my friends' (Female Student 1).

['I practice past-year papers a lot' (Female Student 5).

They also sought to understand and memorise the subject:

[ 'understand the subject, think about it and memorize it many times' (Female Student 5).

[ '[you should] make sure you read until you understand, then memorise it' (Working Male 1).

[ 'I answer past-year paper questions to understand the problems and so I automatically remember how to do it' (Male Student 4).

In the classroom, they asked questions when they did not understand the teacher or had problems during lessons. They also listened to their teachers and obeyed the rules at school. Interestingly, the respondents believed that engaging in activities, such as sports and hobbies, and completing their prayers daily contributed to their good academic performance because it alleviated stress from studying and was good for their mental and spiritual health. A few respondents stated that easy internet access contributed to their good performance at school: 'especially when you are doing your homework or revision, then you are stuck in a math[ematics] problem, you could just Google or YouTube it to find the solution' (Male Student 7). Others stated that being in a challenging environment was beneficial: '[when] in an environment where you are surrounded by smarter students and you feel challenged, then you need to study hard as well' (Working Female 7).

Some respondents stated that certain circumstances motivated them to perform well at school. For example, a female respondent stated that being the eldest child in her family motivated her to perform well at school because she wanted to be a 'role model for my siblings ... so they can follow my footsteps and be successful too' (Working Female 6). Another female respondent stated that the need to overcome difficult circumstances, such as economic hardship and family problems, encouraged her to do well at school: 'it motivates me even more to do well at school when I have personal problems at home, either because of family or money ... [l] want to get over with it as soon as possible by studying hard' (Working Female 8).

Friends also played an important role in the respondents' lives as students, and could influence them to achieve better results. The respondents stated that friends who were supportive helped them do their homework, encouraged them, went to classes on time, reminded them that they had to study hard and made sure they were 'on the same boat as theirs' (Female Student 3) during lessons. 'Friends who study a lot' (Male Student 1) tended to influence the respondents and encouraged good habits 'to study' (Working Male 6) and 'do revision regularly' (Female Student 4). Other friends described as a positive influence were always close to the respondents and encouraged them to play sports, undertake other schoolbased activities and join study groups. Hence, having positive friends can promote healthy communication and studying skills.

Parents also helped the respondents perform well at school. This included help via financial assistance, including providing private 'tuition classes' (Female Student 8). A few of the respondents stated that their parents helped by giving constant motivation:

[ 'My parents [motivated me] 'cause they always give you encouragement to study hard. They say getting a job is hard these days, so that is why we have to study hard, so the job is waiting for you, not you waiting for the job. So you can see [that] the pressure is there to do your best' (Male Student 3).

[ 'Parents give you wise words ... words of wisdom. They told us stories about their past and how it was difficult back then, but still they worked hard to be where they are now. And so it's best not to waste your parents' money, but just study hard, study smart [smiles]' (Female Student 7).

[ 'Apart from giving us motivation, they [parents] also compare us to those who are unfortunate, who want to study, but don't have the means to do so-it's so sad, but true. They told us to be thankful always-almost every day! Because here in Brunei, the education is free and we should be thankful for being a student and for that reason' (Male Student 5). 
The effect of teaching methods and school facilities and environment on students' academic performance.

Regarding teaching methods, the respondents believed that teachers who were helpful, had good teaching techniques and constantly provided encouragement and motivation or one-to-one lessons to students contributed to their good academic performance at school:

[ 'Teachers who are helpful-helping me in solving problems in maths. They don't scold you for not knowing how to answer it, but they are willing to help you, encourage you to do better' (Working Male 8).

口 'Whenever we have problems in class, or about homework, she will ask us why we couldn't do it and she will immediately show us how to do it' (Working Female 4).

口 'Teachers who help you do anything in class' (Male Student 3).

口 'They [teachers] motivate you, encourage you ... "you should do this, you should do that"-make it right for you, give good examples in lessons' (Female Student 6).

口' 'l like it when teachers give extra time to each one of us, to teach us privately so that we could understand even better' (Female Student 1).

Some respondents stated that they sought inspiration from teachers' stories or encouragement:

[ 'Sometimes when teachers tell us an amazing story about someone else who succeed[ed] as a result of studying hard, I will be easily inspired by it' (Working Female 3).

[ 'Teachers always give you encouragement, maybe in the form of compliments or words of wisdom, stories of amazing people-it's so inspiring' (Male Student 5).

However, some respondents stated that teachers could also worsen their academic performance. They found that some teachers gave less attention to students and ignored their body language in the classroom: 'the teacher did not notice that the students are having a hard time to understand what she's teaching, or even when students are getting sleepy in her classroom' (Working Female 2). One respondent stated that teachers provided incomplete lessons in classroom: 'She doesn't give enough lesson. When she comes, she teach for a while, then after that, she'll just ask us to read on our own, while she's sitting down at her desk playing with her mobile or reading' (Female Student 8). This respondent undertook tuition classes to supplement the lessons taught at school. Another respondent blamed teachers for giving less homework: 'less homework was given, so [there was] less revision to do at home' (Male Student 4)]. A few other respondents stated that their teachers were 'too strict' (Working Female 7) and showed little compassion towards their students, which made the students unhappy or unwilling to study the subject being taught.

The respondents agreed that school facilities and environment could affect academic performance. First, they commented on the number of students in a classroom, with less than 20 or 30 students making it is easier for the teacher to control and teach, and easier for the students to listen to the teacher and understand the lessons: 'with lesser students in the class, I concentrate in class even more and I perform better in the examinations' (Female Student 7). Second, they claimed that schools with good facilities-such as a library, photocopying machines, benches, study tables and good canteensenhanced the will to study and made it easier to have group discussions with other students and teachers. A few respondents expressed satisfaction with their boarding schools:

['I get to meet my friends all the time, which makes studying easier' (Female Student 6).

[ 'they [the boarding school] prepare meals for you and, after that, you can study in your room without any distractions, but you can seek help from your roommates if you have any problems, which is totally cool' (Male Student 5).

However, some respondents had the opposite circumstances. They stated that they had more than 25 students in their classroom, which made it difficult for the teacher to control and teach, and the students struggled to study and listen. This could also have resulted from the seating arrangement in the class. Students who sat at the back of the class experienced difficulty in listening to their teachers. One of the respondents claimed that the school offered few extracurricular activities, which lessened his interest in studying and made him find school 'boring' (Working Male 4). This could be due to the lack 
of teacher expertise in extracurricular activities, such as 'martial arts, chess and football' (Male Student 3). Other respondents found that a negative environment reduced their concentration and motivation to study:

口 'bad environment-your friends are always arguing or fighting with you, bullying you, stab you in the back, and sometimes with your family members' (Female Student 2).

[ 'family problems-for example, you see your parents or older siblings arguing with each other, it confuses, stresses you out' (Working Male 1).

口 'dirty environment ... hard to concentrate in the class' (Male Student 1).

Other respondents were affected by peer pressure:

[ 'everyone is pressuring you to study hard, and being reminded of the bad consequences if you don't study hard' (Male Student 4).

[ 'at times, your friends influenced you to escape from classes and you know it's a wrong thing to do, but you just feel that you have to join them' (Working Female 3).

Problems or challenges to academic performance at school.

The majority of respondents found that they were easily distracted by one or more of the following: friends, boyfriends or girlfriends, social media (such as Facebook, Twitter and Instagram), internet, playing games and television. Most agreed that they spent a lot of time with these distractions, and procrastinated rather than studying or doing their homework:

[ 'Distractions? [Laughs. ] A lot! Friends, mobile phones, internet, games, television ... everyday, but depends on the mood. Sometimes I got distracted until I forgot what to do [for school]' (Working Male 2).

[ 'If distractions, l'd have to say Facebook and mobile phones ... a bit of delay in doing my homework' (Female Student 7).

[ 'Distraction from people—friends, girlfriends (but not so much). From television-yes. From Facebook and Instagramsometimes ... Not really to the point that I didn't do my homework or study at all, but I tend to procrastinate [by doing] the things I want to do' (Male Student 5).

口'I think my friends 'cause they always disturb me in the class when the teacher is right in front explaining' (Female Student 6).

[ 'Games. I like to play games with my friends, either online or through PlayStation' (Male Student 6).

[ 'Friends, Facebook, mobiles, television and internet' (Male Student 8).

Some respondents complained about their friends as negative influences. They stated that they were talkative:

[ 'when teachers talk, they talk too, so [it is] hard to listen to class' (Working Male 3).

口 'they talk a lot, especially during the lesson' (Working Female 7).

They stated that their friends encouraged them to engage in unproductive behaviour:

[ 'friends who invite you to escape from classes, or break the school's rules' (Working Male 1).

[ 'friends who encourage you to do bad things in school, which includes copying homework from your friends, bullying people' (Working Male 5).

They also stated that their friends did not motivate them to study:

[. 'no motivation from friends 'cause they don't study well either' (Female Student 8).

[ 'why would you study when your friends also don't do the same?' (Working Male 2).

\ 'friends who don't motivate you to study' (Female Student 4).

Most of the respondents agreed that there were certain negative factors that hindered their academic progress, including: 


\section{Laziness:}

'can't really cope with laziness' (Male Student 1).

'being lazy' (Female Student 1).

'cannot help but feel lazy' (Working Female 3).

'lazy to do anything' (Male Student 4).

2. Lack of time:

'so many things to do, yet so little time' (Male Student 6).

3. Lack of motivation:

'in need of people to push you' (Female Student 5).

'no motivation to study' (Male Student 7).

4. Lack of concentration:

'hard to concentrate in class' (Female Student 3).

'lack of concentration' (Working Female 4).

5. Heavy workload:

'I have so much homework and revision to do' (Male Student 2).

'The teachers give so much homework to do and the deadline is ... tomorrow' (Female Student 8).

'Last-minute homework given by the teacher and you know you have to catch up with your revision too-how is that possible?' (Male Student 8).

6. Family problems:

'Family problems at home-it slows me down in studying' (Working Male 3).

7. Health problems:

'I have sleeping problem—insomnia. I think. I just can't sleep at night, so in daytime, I will be very sleepy' (Male Student 4).

'I have a problem with my heart-the valve is not normal, so it affects my health' (Working Female 1).

8. Little interest in studying:

'Less interest in studying chemistry—it's so hard' (Female Student 7).

'subjects like accounting—so boring and hard to understand' (Working Male 4).

9. High parental expectations:

'Parents who have high expectations and they will put pressure you to study hard' (Male Student 5).

'Parents expect too much from me and I'm not sure if I can cope with my studies-it's so difficult!' (Female Student 2).

Early entry to workplace.

The majority of respondents who started working after college did not perform well in mathematics and English. Since they did not meet the university's admission criteria, they had no choice but to begin working earlier. The following include the reasons for these respondents beginning work earlier:

1. Financial problems: 
'I started working because I have financial problems-not only personally, but my family too. My family have been supporting me since I was little, especially my parents. So I guess it's time to repay them by helping them and give them financial support' (Full-time Senior Assistant, Working Male 1).

'I work to support myself and my family's financial issues. It's been hard for me since I'm the second eldest, and my parents are old and they have retired already' (Full-time Customer Service Representative, Working Male 8).

'The reason why I work is to overcome my financial issues and also to help my family financially. There is always the case of insufficient money whenever my family or I want to spend on anything especially on what we need than on what we want' (Full-time Clerk, Working Female 1).

'I want to help my parents financially [and] if I continue studying, it would take a long time to finish' (Full-time Sales Assistant, Working Female 2).

\section{Lack of qualifications:}

'My A Level results were not very satisfying. My points were not enough to go to university, so I had no choice to but to start working' (Full-time Customer Service Representative, Working Male 4).

'I choose to work because I got rejected from UBD. My results were not good, so there's nothing I could do but to work' (Full-time Clerk, Working Female 7).

'After A Level Examination, I applied for university, but the university did not accept me. I was rejected. I guessed it's because of my results, which are not okay. So I applied for a job in JIS [Jerudong International School] and I got it' (Fulltime Assistant Teacher, Working Female 4).

'I got rejected from UNISSA [Universiti Islam Sharif Ali] and KUPU [Kolej Universiti Perguruan Ugama Seri Begawan]don't know for what reason, possibly 'cause my points are not enough. So l'm not giving up, but l'm sulking a bit [laughs] that I couldn't get in to uni[versity], and here I am, working!' (Full-time Clerk, Working Female 1).

\section{Avoiding wasting time:}

'While waiting for acceptance in any universities, I applied for any jobs that related with my qualification. Maybe it won't waste my time for waiting for any offers from the university to continue my study' (Full-time Statistical Clerk, Working Male 5).

\section{Gaining experience:}

'I want to gain experience from working and later I may be eligible to apply for JPKE [Department of Economic Planning and Development] Scholarship' (Full-time Finance Assistant, Working Male 6).

'I work to gain experience, which really helps a lot in improving myself in many ways, learn the real life about how to deal with different people, and the best part is l've got my own money' (Full-time Administration Collector, Working Female 6).

5. No interest in further study:

'I don't want to study anymore-that's why I decided to work' (Full-time Clerk and Cashier, Working Female 3).

\section{Lack of confidence to study further:}

'I gave up because I was too disappointed with math[ematics] results. I didn't score well enough to go to university, I guess. With UBD's recent change in its entry requirements, I heard it's getting harder to get in. This really makes me feel less confident about going to uni[versity]. So, I tried my luck to find work. I applied to many adverts on vacancies both in government and private sectors. Fortunately, I got a job offer and I accept it immediately' (Full-time Pension Officer, Working Female 5).

Of the 16 respondents, three males and one female declined to answer why they chose to work. Of the 16 working respondents interviewed, three males and two females were taking classes at night for either a degree or higher national diploma qualification at local private colleges. Their reasons for doing so included seeking an increased salary, seeking a better job and determining whether they would be more successful than in their previous examination. 


\section{Sources of help in achievement at school.}

Students normally have sources of help in achieving good grades at school. These can include motivation, encouragement or inspiration to succeed. A source of help can be anyone or anything; however, in this study, the respondents were given four choices: parents, teachers, friends and themselves; and they were selected based on the circle of relationships of a student. The results indicated that the majority of respondents used their parents as their source of help. They claimed that their parents gave the most support, motivation and encouragement. The second highest source of help was teachers, followed by themselves, and then friends. Table 3 indicates the number of female and male respondents and their choices of source of help.

Table 3

Number of Female and Male Respondents and Their Choice of Source of Help

\begin{tabular}{|c|c|c|c|c|c|c|}
\hline \multirow{2}{*}{ Gender } & & \multicolumn{4}{|c|}{ Sources of help } & \multirow{2}{*}{ TOTAL } \\
\hline & & Parents & Teachers & Friends & Myself & \\
\hline \multirow{2}{*}{ Working male respondents } & Count & 2 & 4 & 0 & 2 & 8 \\
\hline & $\%$ of total & $6.3 \%$ & $12.5 \%$ & $0.0 \%$ & $6.3 \%$ & $25.0 \%$ \\
\hline \multirow{2}{*}{ Working female respondents } & Count & 5 & 1 & 0 & 2 & 8 \\
\hline & $\%$ of total & $15.6 \%$ & $3.1 \%$ & $0.0 \%$ & $6.3 \%$ & $25.0 \%$ \\
\hline \multirow{2}{*}{ Male students } & Count & 5 & 2 & 0 & 1 & 8 \\
\hline & $\%$ of total & $15.6 \%$ & $6.3 \%$ & $0.0 \%$ & 3. $1 \%$ & $25.0 \%$ \\
\hline \multirow{2}{*}{ Female students } & Count & 5 & 1 & 2 & 0 & 8 \\
\hline & $\%$ of total & $15.6 \%$ & $3.1 \%$ & $6.3 \%$ & $0.0 \%$ & $25.0 \%$ \\
\hline \multirow{2}{*}{ TOTAL } & Count & 17 & 8 & 2 & 5 & 32 \\
\hline & $\%$ of total & $53.1 \%$ & $25.0 \%$ & $6.3 \%$ & $15.6 \%$ & $100.0 \%$ \\
\hline
\end{tabular}

\section{Discussion}

The present study attempts to explain gender disparity in academic achievement in Brunei tertiary education in a qualitative manner. The findings in this study confirmed that there are gender differences in academic performance between female and male students, but to achieve good academic results, the study shows that there are gender similirities practiced by the students, as explained earlier. There are many factors contributing to gender differences in academic achievement and to produce an ultimate list of such factors would be almost impossible because it encompasses a wide range of issues / concepts, such as the the relationship of the learning processes and the biology of the human brain (Hinton, Miyamoto and Della-Chiesa, 2008); personality measures for predicting academic performance (Poropat, 2011); collaborative learning mechanisms (Robinson and Lenkin, 2012); learning strategies (Weinstein and Mayer, 1986; Anthony, 1996; Yipa, 2012); students' self-efficacy (Bagaka, 2011); socioeconomic status of the students (Wenglinsky, 1998; Sirin, 2005; Juma, Simatwa and Ayodo, 2012) and many more.

The second finding (teaching methods and school facilities and environment may affect students' academic performance) is also similar in other studies, such as Day, Sammons and Kington (2008) and Teoh, Abdullah, Roslan and Mohd Daud (2014). Moreover, few other studies, such as Blömeke, Suhl and Kaiser (2011) and Sencer, Niyazi and Alpaslan (2011) touched on the cultural differences in the effectiveness of teacher education and teaching styles. In general, teachers and schools (as a whole) both play important role in developing students' learning attitudes and personalities as well maintaining students' good academic performance. In other words, the teachers' education and schools' level of quality are on a par with students' academic achievement and performance.

Like other students in many countries, Bruneian students also faced problems and challenges faced in academic performance or achievement at school. Therefore in this study, it provides practical implications for parents and teaching implications for teachers, schools and the government. In terms of parents' role, in brief, parents (Dato Haji Metussin, 2016):

have a role to play in encouraging the performance of students at school;

should be exposed to pre-school education and parenting skills to improve the home learning environment (Cassen and Kingdon, 2007). 
should spend time with their children so that they know their children's progress in school, in terms of learning experiences obtained from teachers and social skills acquired by people at school.

should also make an effort to help their children via giving moral and emotional support and attending teacher-parent meetings, school activities and other social events organised by the school.

Based on the findings, there are many educational interventions for the teachers to apply but generally, the teachers have to:

use teaching methods that attract students' interest and intrinsic motivation in the subjects (Mundia, 2010a).

use language that is suitable to the students' level of knowledge (Kalisk, 1979, as cited in Mundia, 2010a).

emphasize remedial teaching which is a multifaceted approach aimed to deliver students' specific needs in education, such as via one-on-one sessions between the student and teacher, small group discussions, task-analysis strategies, and visual aids or computer-based work to stimulate students' cognitive ability (Martinez, 1987; Heward, 1996; Hunt \& Goets, 1997; Mundia, 2010a).

On the other hand, schools - which serves as educational and social settings for both students and teachers:

must encourage students' engagement in education-whether by developing learnt skills or natural talent-both in practical and vocational education. This would benefit students who cannot afford higher education, and serve as an alternative to higher education (Cassen and Kingdon, 2007).

must have adequate counselling and psychotherapy resources to help students with personal and academic problems as well as behavioural and mental health problems.

with different cultural backgrounds are unique; thus, they must provide teachers from different cultural backgrounds with proper training and briefings before starting teaching.

should limit the amount of administrative and maintenance duties allocated to teachers (Wong, 2014).

Given that the government controls the education system in Brunei, the government should provide lectures or familial training to new parents or parents who lack necessary parenting skills, focusing on the welfare of families who are disadvantaged in terms of education, financial resources and house affairs; and preventing these families' children being vulnerable to negative attitudes and social behaviours. The government must contribute financial help to disadvantaged families in order to ensure that children can attend school. The government should improve features of the school system, reallocate and enhance school expenditure in order to try to help reduce the gender gap (Cassen and Kingdon, 2007).

\section{Conclusion}

If gender gap in academic achievement persists, it will cause a detrimental gender imbalance population between female and male students admitted to colleges and universities, and consequently it will affect the whole society in terms of family and labour market institutions. The dominance of females occupying important positions in society, there is a probability that society will favour women, rather than pursuing gender equality, and that the birth rate will decrease (as women pursue careers, rather than marrying and having children). Simultaneously, males are more likely to have low-paid occupations or be unemployed, to persist in their bad attitudes, to have low motivation to improve their quality of life, to delay marital life and to have financial problems. Therefore, it is recommended that educational stakeholders (such as teachers, schools, policy-makers etc. ) play their important role in the education system to reduce the gender differences in academic achievement. The only limitation is that this study lacks of quantitative component to supplement the data and findings, so therefore a further mixed-methods research is required to acquire deeper understanding of the problem and the needed solutions.

\section{References}

[1] Anthony, G. (1996). When Mathematics Students Fail to Use Appropriate Learning Strategies. Mathematics Education Research Journal, 8 (1), 23-37. 
[2] Arthur, J., Waring, M., Coe, R. \& Hedges, L. V. (Eds. ). (2012). Research Methods and Methodologies in Education. Thousand Oaks, CA: Sage Publications.

[3] Bagaka, J. G. (2011). The role of teacher characteristics and practices on upper secondary students' selfefficacy in Nyanza province of Kenya: A multilevel analysis. International Journal of Science and Mathematics Education, 9, 817-842.

[4] Blömeke, S., Suhl, U. \& Kaiser, G. (2011). Teacher education effectiveness: Quality and equity of future primary teachers' mathematics and mathematics pedagogical content knowledge. Journal of Teacher Education, 62(2), 154-171.

[5] Cassen, R. \& Kingdon, G. (2007). Tackling low educational achievement. Joseph Rowntree Foundation. Retrieved from http://www. jrf. org. uk/sites/files/jrf/2063-education-schools-achievement. pdf

[6] Creswell, J. W. (2009). Research design: Qualitative, quantitative, and mixed methods approaches (3rd ed. ). Thousand Oaks: Sage Publications.

[7] Dato Haji Metussin, H. (2016). Where Are the Males? Gender Gap in Higher Education (Potential Causal Factors of the Gender Gap in Higher Education in Brunei and Implications for Educators). Saarbrücken, Germany: Scholar's Press.

[8] Day, C., Sammons, P. and Kington, A. (2008) Effective classroom practice: A mixed method study of influences and outcomes: Full research report, ESRC End of Award Report, RES-000-23-1564. Swindon, UK:ESRC.

[9] Department of Planning, Development and Research. (2010). Education Statistics Brunei Darussalam. Brunei Darussalam: Ministry of Education.

[10] Department of Statistics. (2011). Brunei Darussalam Statistical Yearbook 2011. Brunei Darussalam: Department of Economic Planning and Development, Prime Ministers Office.

[11] Heward, W. L. (1996). Exceptional Children: An Introduction to Special Education. Englewood Cliffs: Merrill/ Prentice Hall.

[12] Hinton, C., Miyamoto, K., \& Della-Chiesa, B. (2008). Brain research, learning and emotions: implications for education research, policy and practice. European Journal of Education, 43 (1), 87-103.

[13] Hunt, P., \& Goetz, L. (1997). Research on inclusive education programs, practices and outcomes for students with severe disabilities. Journal of Special Education, 31 (1): 3-29.

[14] Juma, L. S. A., Simatwa, E. M., \& Ayodo, T. M. O. (2012). Impact of family socio-economic status on girl students' academic achievement in secondary schools in Kenya: A case study of Kisumu East District. Educational Research, (ISSN: 2141-5161) Vol, 3(3), 297-310.

[15] Kalisk, L. (1979). Teaching mathematics to the child with specific learning disability. Focus on Learning Problems in Mathematics, 1 (1), 60-73.

[16] Lincoln, Y. S. \& Guba, E. G. (1985). Naturalistic inquiry. Newbury Park, CA: Sage Publications.

[17] Martinez, J. G. A. (1987). Preventing math anxiety: a prescription. Academic Therapy, 23 (2), 117-125.

[18] Mundia, L. (1998). The status of technical subjects in Papua New Guinea provincial high schools: A survey of attitudes. Science, Technology and Development. 16 (2): 104-111.

[19] Mundia, L. (2006). Aggressive behaviour among Swazi upper primary and junior secondary school students: implications for ongoing educational reforms concerning inclusive education. International Journal of Special Education, 21 (3), 58-67.

[20] Mundia, L. (2010a). Problems in learning mathematics: Comparison of Brunei junior high school students in classes with and without repeaters. Journal of Mathematics Research, 2 (3), 150-160. 
[21] Mundia, L. (2010b). Prevalence of depression, anxiety and stress in Brunei student teachers. Internet Journal of Mental Health, 6(2). Available online at: http://www. ispub.

com/journal/the_internet_journal_of_mental_health. html

[22] Mundia, L. (2012a). Policy changes in Brunei teacher education: Implications for the selection of trainee teachers. The Education Forum, 76 (3), 326-342.

[23] Mundia, L. (2012b). The Assessment of Mathematics Learning Difficulties in a Primary Grade 4 Child with High Support Needs: Mixed Methods Approach. International Electronic Journal of Elementary Education. 4 (2), 347-366.

[24] Patton, M. Q. (1990). Qualitative evaluation and research methods. Newbury Park, CA: Sage Publications.

[25] Poropat, A. E. (2011). The Eysenckian personality factors and their correlations with academic performance. British Journal of Educational Psychology, 81, 41-58.

[26] Robinson, N., \& Leikin, R. (2012). One teacher, two lessons: The lesson study process. International Journal of Science and Mathematics Education, 10, 139-161.

[27] Sencer, C. M., Niyazi, E. \& Alpaslan, S. (2011). A Comparative Study of South Korea and Turkey: Attitudes, Beliefs, and Creative Student Oriented Teaching Practices of Middle School Mathematics Teachers. Journal of the Korean Society of Mathematical Education Series D: Research in Mathematical Education, 15(3), 295-310.

[28] Sirin, S. R. (2005). Socioeconomic status and academic achievement: A meta-analytic review of research. Review of Educational Research, 75(3), 417-453.

[29] Teoh, H. C., Abdullah, M. C., Roslan, S., \& Daud, S. M. (2014). Assessing students approaches to learning using a matrix framework in a Malaysian public university. SpringerPlus, 3(1), 54.

[30] Weinstein, C. E., \& Mayer, R. E. (1986). The teaching of learning strategies. In M. Wittrock (Ed. ), Handbook of research on teaching. New York, NY: Macmillan.

[31] Wenglinsky, H. (1998). Finance Equalization and Within-School Equity: The Relationship Between Education Spending and the Social Distribution of Achievement. Educational Evaluation and Policy Analysis, 20(4), 269283. Retrieved from http://doi. org/10. 3102/01623737020004269

[32] Wong, A. (2014, August 27). Reduce admin work on teachers: MoE. The Brunei Times. Retrieved from http://www. bt. com. bn/news-national/2014/08/27/reduce-admin-work-teachers-moe

[33] Yipa, M. C. W. (2012). Learning strategies and self-efficacy as predictors of academic performance: a preliminary study. Quality in Higher Education, 18 (1), 23-34.

\section{APPENDIX I}

\section{THE MAJOR OCCUPATION GROUPS}

\begin{tabular}{|l|l|}
\hline NO. & GROUP OCCUPATION \\
\hline & Workers Not Classified by Occupation \\
\hline & Agriculture, Forestry and Fishery \\
\hline & Mining and Quarrying \\
\hline & Manufacturing \\
\hline & Electricity, Gas, Steam and Air Conditioning Supply \\
\hline & Water Supply; Sewerage, Waste Management and Remediation Activities \\
\hline & Construction \\
\hline & Wholesale and Retail Trade, Repair of Motor Vehicles and Motorcycles \\
\hline & Transportation and Storage \\
\hline & Accommodation and Food Service Activities \\
\hline & Finformation and Communication \\
\hline & Real Estate Activities \\
\hline
\end{tabular}




\begin{tabular}{|l|l|}
\hline & Professional, Scientific and Technical Activities \\
\hline & Administrative and Support Service Activities \\
\hline & Public Administration and Defence; Compulsory Social Security \\
\hline & Education \\
\hline & Human Health and Social Work Activities \\
\hline & Arts, Entertainment and Recreation \\
\hline & Other Service Activities \\
\hline & Housewife \\
\hline & Retired \\
\hline 00 & Missing Data \\
\hline
\end{tabular}

\section{NOTE:}

Group No. 00 means 'Missing Data' (Participants chose not to answer the question).

Group No. $1-20$ belongs to:

Industry Group - Referring to International Standard Industrial Classification of All Economic Activities (ISIC) Rev. 4 Industry Classifications.

Occupation Group - Using Brunei Darussalam Standard Classification of Occupations (BDSCO) 2008, with reference to International Standard Classification of Occupations (ISCO) 2008 Classifications. 